\title{
Operational Excellence and its impact on hazardous waste management in the automotive industry
}

\section{La excelencia operativa y su impacto en la gestión de residuos peligrosos en la industria del automóvil}

\author{
SOTO-LEYVA, Yasmin†*, BONES-MARTÍNEZ, Rosalía and SANTOS-OSORIO, Arturo
}

Tecnológico Nacional de México/Instituto Tecnológico Superior de Huauchinango

ID $1^{\text {st }}$ Author: Yasmin, Soto-Leyva / ORC ID: 0000-0003-2652-7065, CVU CONACYT ID: 951464

ID $1^{\text {st }}$ Co-author: Rosalía, Bones Martínez / ORC ID: 0000-0001-8829-9737, CVU CONACYT ID: 368744

ID $2^{\text {nd }}$ Co-author: Arturo, Santos-Osorio / ORC ID: 0000-0003-3643-5770, CVU CONACYT ID: 951024

DOI: $10.35429 / J I O .2021 .9 .5 .8 .14$

Received July 28, 2021; Accepted December 30, 2021

\begin{abstract}
Currently the composition of the products is more complex, therefore, also their residues, being a concern for governments and productive organizations. The automotive industry at the national level is the productive sector that occupies the third place in generation of hazardous waste, therefore, the objective of this application is focused on implementing an effective strategy to reduce the negative impact of this waste, the selected strategy is Known as OPEX (Operational Excellence), it is in charge of managing hazardous waste to reduce expired material; The case analyzed was applied in the temporary storage of hazardous waste, obtaining beneficial results, exposed in the increase in the registration of expired material at a percentage rate of $40 \%$ and a decrease of $17.21 \%$ in the powder paint residue, the methodology used mainly It is operational excellence complemented by lean manufacturing tools focused on the creation of effective operational flows, to deliver the maximum value, aligned to the mission, vision and corporate procedures, as well as to the client's requirements, for this the DEMING circle is applied and other techniques for the reduction of expired materials, hazardous waste and legally established actions.
\end{abstract}

Automotive, Warehouse, Waste, OPEX

\begin{abstract}
Resumen
Actualmente la composición de los productos es más compleja, por lo tanto, también sus residuos, siendo una preocupación para los gobiernos y organizaciones productivas. La industria automotriz a nivel nacional es el sector productivo que ocupa el tercer lugar en generación de residuos peligrosos, por lo tanto, el objetivo de esta aplicación se enfoca en implementar una estrategia efectiva para reducir el impacto negativo de estos residuos, la estrategia seleccionada es Conocida como OPEX (Excelencia Operacional), se encarga de gestionar los residuos peligrosos para reducir el material caducado; El caso analizado se aplicó en el almacenamiento temporal de residuos peligrosos, obteniendo resultados benéficos, expuestos en el incremento en el registro de material caducado en un porcentaje del $40 \%$ y una disminución del $17.21 \%$ en el residuo de pintura en polvo, la metodología utilizada principalmente Es la excelencia operativa complementada con herramientas de manufactura esbelta enfocada a la creación de flujos operativos efectivos, para entregar el máximo valor, alineados a la misión, visión y procedimientos corporativos, así como a los requerimientos del cliente, para ello se aplica el círculo DEMING y otras técnicas para la reducción de materiales caducos, residuos peligrosos y acciones legalmente establecidas.
\end{abstract}

Automoción, Almacén, Residuos, OPEX

Citation: SOTO-LEYVA, Yasmin, BONES-MARTÍNEZ, Rosalía and SANTOS-OSORIO, Arturo. Operational Excellence and its impact on hazardous waste management in the automotive industry. Journal-Industrial Organization. 2021. 5-9: 8-14

\footnotetext{
*Correspondence to Author (yasmin.soto@itsh.edu.mx)

$\dagger$ Researcher contributing first author.
} 


\section{Introduction}

Solid waste management, particularly hazardous waste, is a matter of concern in almost all countries, as the world has become more productive to sustain society's demand, in turn, products are more complex and have decreased. noticeably its life cycle. This results in an increase in the volumes of waste generated with the presence of hazardous materials, leading to the concentration of waste in a given area, putting even more pressure on the ecosystem (Morejón, 2003). The general law of ecological balance and protection of the environment defines as dangerous all waste, in any physical state, which, due to its corrosive, toxic, poisonous, reactive, explosive, flammable, biological, infectious or irritant characteristics, represents a danger to ecological balance or the environment;

According to this definition, practically any substance could be considered dangerous; however, the factors of greatest importance to society are infectiousness and toxicity. The generation of hazardous waste and waste of special handling worldwide is worrying, in the magnitude in which these put health at risk, considering that the more developed a country is, the greater amount of hazardous waste it will generate, such is the case of The United States of America, which originates an average of $37,000,000$ tons of hazardous waste worldwide (American Assembly, 1982), followed by Germany and China; while, in Latin America, Mexico occupies the first place generating 2, 000,000 million tons of hazardous waste annually (Mercader, 2002).

"In Mexico, more than $90 \%$ of the hazardous waste produced per year is improperly managed, demonstrating that hazardous waste is abnormally available in the environment, polluting rivers, streams, deserts, among others," which has led to face an important study challenge in hazardous waste management (SEMARNAP, 1996).

This project refers to the topic "Operational Excellence (OPEX) and its impact on hazardous waste management" within an Automotive Manufacturing plant located in Mexican territory.
The company maintains a one-time interest, by generating a clear commitment to become a leading global green organization, working to create a society based on low-carbon recycling through the application of a wide range of advanced technologies supported by the continuous actions of its employees and its high environmental commitment, for this reason it has taken actions such as the reduction of hazardous waste. To achieve this, the methodology proposed by Dr. Luis Amendola was used, applying the following phases (Cuatrecasas, 2011):

Phase 1: Develop the strategy, in this phase the main problem was identified and quantified by separating the quantities of expired waste corresponding to each area, the costs for waste were calculated.

Phase 2: Plan the strategy, in this stage the organization was aligned, seeking to generate commitment with senior management, showing the main problem to all the departments involved, establishing collaborative teams, as well as actions that support in the reduction of generation of expired waste.

Phase 3: Application of tools, for this stage methodological tools were used, such as brainstorming, Ishikawa diagram, Pareto diagram, which helped in the adequate planning of improvement actions, carrying out each one of them chronologically.

The corresponding results of the OPEX application are visualized through the monitoring and evaluation of the different indicators, which are represented by the benefits obtained in the entry records of expired material to the warehouse area and the reduction of the main waste, concluding that The operational tool implemented brought with it economic and environmental benefits (reduction of waste generation) that arose from the improvement actions and the strategies developed.

\section{Methodology}

The methodology for the development of this application is shown below: 


\section{Phase 1 Develop the strategy}

With the aim of reducing the arrival of expired material to the temporary hazardous waste area for proper management, through the application of operational excellence OPEX., In the first instance, we proceeded to know the problem that existed at that time, for which the analyzed the incidents in the entry and registration of material temporarily available in the warehouse. In the same way, the real weight per month in $\mathrm{kg}$ of the main waste was quantified (Graph 1.1 Concentrate of hazardous waste per month in kilos).

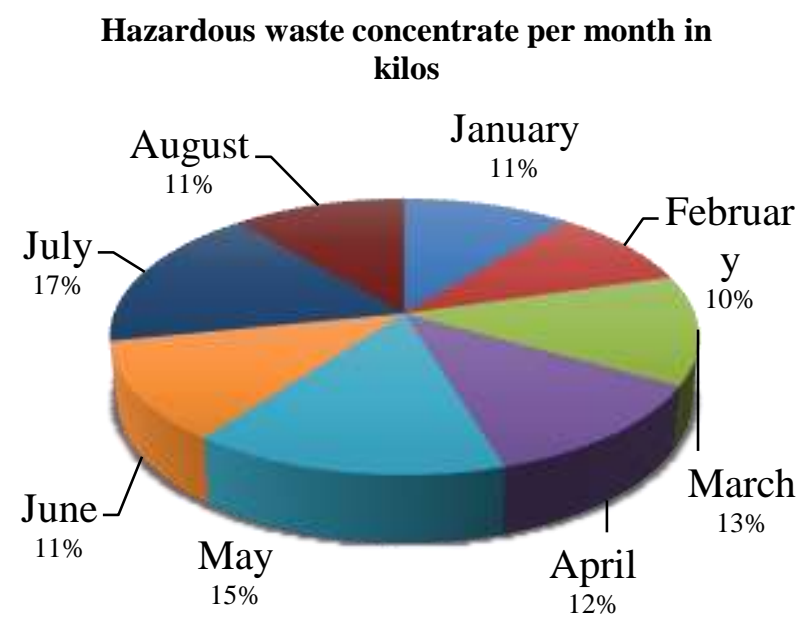

Graph 1.1 Concentrate of hazardous waste per month in kilos

Source of consultation: Own Elaboration

With the information obtained, expired materials were specifically identified from January to August 2020 (Table 1.1 Total hazardous waste concentration).

\begin{tabular}{|c|c|c|}
\hline Hazardous waste & Kg. & $\%$ \\
\hline Impregnated Plastic Voids & 1394 & 6 \\
\hline Impregnated Metal Voids & 3169 & 13 \\
\hline Solid Varnish & 4404 & 18 \\
\hline Liquid Varnish & 1643 & 7 \\
\hline Powder paint & 7120 & 30 \\
\hline Silica & 3210 & 13 \\
\hline Spent Oil & 2809 & 12 \\
\hline Welding Slag & 97 & 0.4 \\
\hline Lamps & 60 & 0.2 \\
\hline Acetone & 21 & 0.1 \\
\hline Silicon & 127 & 0.5 \\
\hline Hexane & 3 & .01 \\
\hline Per butyl & 13 & 0.1 \\
\hline
\end{tabular}

Table 1.1 Total hazardous waste concentration Source of consultation: Own Elaboration
As it is observed that the material with the greatest quantity in the warehouse area is powder paint (Table 1.1 Total concentration of hazardous waste), this observation leads to the analysis of the generating cause of said storage, concluding that the source of origin of the accumulation of the material was the production area (Figure 1.1 Main generating areas of hazardous material in the operating flow).

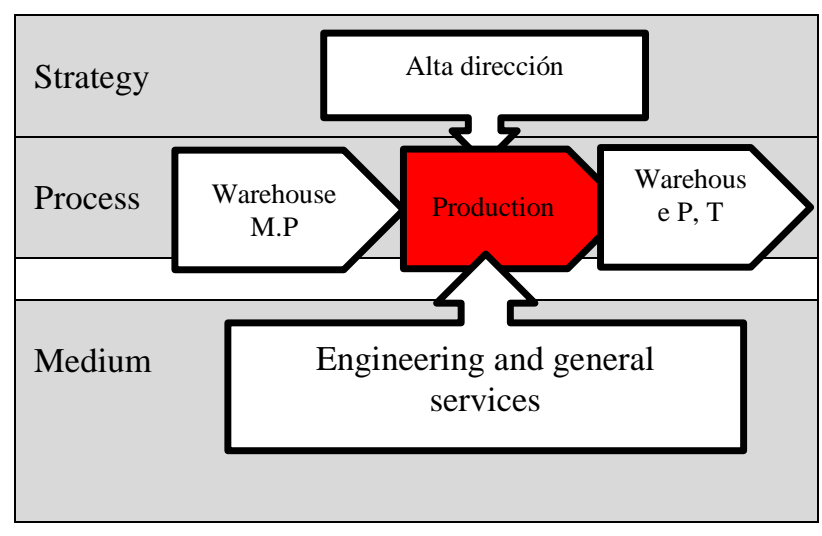

Figure 1.1 Main generating areas of hazardous material in the operating flow

Source of consultation: Own Elaboration

Subsequently, the total arrivals to the temporary hazardous waste area were reviewed, it was observed that of 42 reports only 10 were registered in the $\log$, this is equivalent to $24 \%$, the rest were re-entered the production process adopting different analyzes and uses of the production line. Therefore, the manager held a meeting requesting the assistance of senior management where he pointed out the importance of taking immediate actions that provide solutions, to avoid the accumulation of waste since it was observed that from January to August approximately 7, $210 \mathrm{~kg}$ of powder paint with an average cost of $\$ 231.31$ per kilogram, this is equivalent to a monetary loss of $\$$ $102,932.95$ in an analysis period of 8 months, considering a monthly average of $902 \mathrm{~kg}$.

\section{Phase 2 Plan the strategy}

For the development of the phase, the following stages were followed (Figure 1.2 Stages to plan the strategy): 


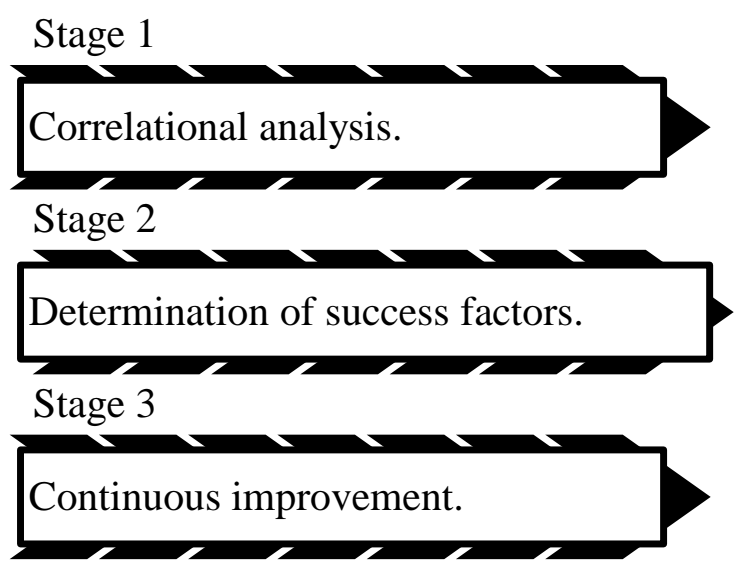

Figure 1.2 Stages to plan the strategy Source of consultation: Own Elaboration

Stage 1) Correlational analysis: the relationship between the different categorical variables was determined, this process began with the investigation of the records at the highest incident points, identifying the months of March, May and July 2020, being the month of July where there was a higher generation of expired material with a total of 17\% (Graph 1.1 Concentrate of hazardous waste per month in kilos); Next, the work system applied in the arrival and departure of the material was analyzed, considering that this time interval is designated to investigate the origin and make the decision of disposal or final disposal. Subsequently, the solution ideas were contextualized to plan the optimal strategy.

Stage 2) The planning of the strategy was carried out through a critical analysis in which the main stakeholders participated, as well as the areas affected by the described problem, including the following departments: Production, planning, purchase of materials, raw material warehouse, temporary storage of hazardous waste, shipments to final disposal of hazardous waste. The strategy to follow began with a sequence of meetings with senior management, where various topics were discussed, concluding with the following ideas:

\section{The situation of excessive generation of hazardous waste. \\ 2. The importance in the supply chain, the direct impact on the product. \\ 3. Costs related to expired material.}

Subsequently, according to the problem, the Critical Success Factors (CRF) were defined (Figure 1.3 Critical success factors)

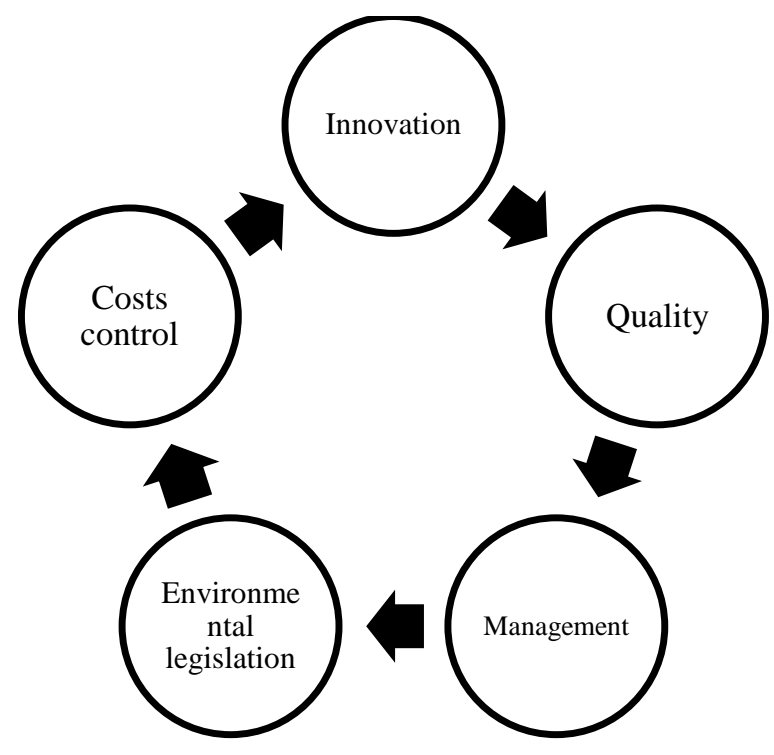

Figure 1.3 Critical success factors

Source of consultation: Own Elaboration

Stage 3) For continuous improvement, a work team was created, with the participation of the following areas: Senior management, environment, production and warehouse. The high-performance team analyzed various issues, including the following: Total amount of hazardous waste to date, amount of expired material from warehouse, amount of expired material that arrives at the hazardous waste warehouse, amount of powder paint that entered the hazardous waste warehouse.

\section{Phase 3 Application of tolos}

To properly plan the operations, various tools were used. In the first instance, brainstorming was applied, followed by this technique, an Ishikawa diagram was implemented, where the possible causes that originated the expired material were observed in a general way; By using the $6 \mathrm{M}$, an effective solution to the problem was identified and proposed. Taking into account the two work tools mentioned above, a registry was created to generate followup to the value chain. Subsequently, a Pareto diagram was made that allowed assigning an order of priorities showing the trivial problems of the non-trivial ones, within this tool it was taken into account that the distribution of the effects as their possible causes is not a linear process, considering that the $20 \%$ of the total causes originate $80 \%$ of the effects and internal rebounds of the predicted behavior.

With the intention of mitigating the problem, the main and/or priority activities in the short, medium and long term were determined, the planning is described below:

SOTO-LEYVA, Yasmin, BONES-MARTÍNEZ, Rosalía and SANTOS-OSORIO, Arturo. Operational Excellence and its impact on hazardous waste management in the automotive industry. JournalIndustrial Organization. 2021 
Short-term: Completion and submission of a registration of complete substances that they contain, expiration date, need for thermal control and control range. The activities required for short-term compliance were established as significant actions, these activities seek to audit the warehouse area through the following operations: 1) Analysis of the system's functionality, 2) Review of real usage and update of boms, 3) Training of operators, leading group and leading team in the efficiency of consumption of chemical materials (Table 1.2 Significant actions in the short term); With the information obtained from the registry, the calendar of material delivery times was analyzed, as well as possible local suppliers were identified, a format for monitoring and control of expired material was created upon arrival of the temporary storage of hazardous waste and a costing registry for hazardous waste (Dávila, Ponce and Yandum, 2019).

\begin{tabular}{|c|c|c|c|}
\hline Activity & Responsable & Beginning & Finished \\
\hline $\begin{array}{l}\text { Meeting with } \\
\text { interested } \\
\text { parties. }\end{array}$ & $\begin{array}{l}\text { Dept. } \\
\text { Environmental. }\end{array}$ & 16 sept. & 18 sept. \\
\hline $\begin{array}{l}\text { Complete } \\
\text { table of } \\
\text { substances. }\end{array}$ & Dept. Store & 30 sept. & 4 oct. \\
\hline $\begin{array}{l}\text { Check usage } \\
\text { and update } \\
\text { boms. }\end{array}$ & $\begin{array}{l}\text { Production } \\
\text { Department. }\end{array}$ & 16 sept. & 8 nov. \\
\hline $\begin{array}{l}\text { Analysis of } \\
\text { lines with the } \\
\text { highest } \\
\text { generation of } \\
\text { waste. }\end{array}$ & $\begin{array}{l}\text { Dept. } \\
\text { Environmental. }\end{array}$ & 21 oct. & 8 nov. \\
\hline $\begin{array}{l}\text { Create } \\
\text { significant } \\
\text { waste cost } \\
\text { records. }\end{array}$ & $\begin{array}{l}\text { Dept. } \\
\text { Environmental. }\end{array}$ & 28 oct. & 8 nov. \\
\hline $\begin{array}{l}\text { Create } \\
\text { monitoring } \\
\text { and control } \\
\text { formats for } \\
\text { expired } \\
\text { material. }\end{array}$ & $\begin{array}{l}\text { Dept. } \\
\text { Environmental. }\end{array}$ & 4 nov. & 15 nov. \\
\hline $\begin{array}{l}\text { Create } \\
\text { OPEX } \\
\text { procedure. }\end{array}$ & $\begin{array}{l}\text { Dept. } \\
\text { Environmental }\end{array}$ & 28 oct. & 15 nov. \\
\hline $\begin{array}{l}\text { Audit } \\
\text { performance. }\end{array}$ & $\begin{array}{l}\text { Dept. } \\
\text { Environmental }\end{array}$ & 29 oct. & 13 nov. \\
\hline $\begin{array}{l}\text { Operator } \\
\text { training. }\end{array}$ & $\begin{array}{l}\text { Dept. } \\
\text { Environmental }\end{array}$ & 21 oct. & 20 nov. \\
\hline
\end{tabular}

Table 1.2 Significant actions in the short term Source of consultation: Own Elaboration
Medium-term: The lines with the highest generation of hazardous waste were analyzed to develop the OPEX technique, seeking to generate a re-consumption strategy or some other alternative use for expired products (Navarro, 2003).

Long-term: The activities planned within this period of time contemplate that each time a new substance arrives, the registry will be updated and shared with the area involved. If there is expired material, a situation will be sent to the interested persons to decide which alternative to proceed.

\section{Results}

As a result of the application of the methodological part corresponding to Phase 1 and 2 described in the development of the project, different indicators were obtained which are presented below:

1. Documentary analysis.

2. Proposal for improvement.

3. Development of documentary proposal.

For the correct improvement in the management of hazardous waste, the historical data were compared with the current ones (Graph 1.2 Waste register).

Material registration

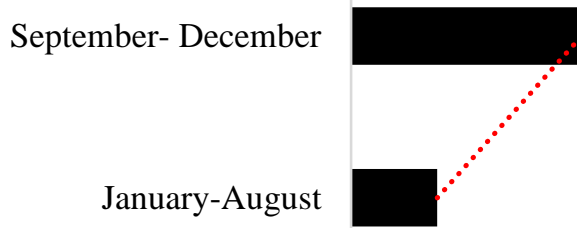

$0 \% \quad 20 \% \quad 40 \% \quad 60 \% 80 \% 100 \%$

Graph 1.2 Waste register

Source of consultation: Own Elaboration

The information observed in the previous graph (Graph 1.2 Waste register) shows that in the January-August period only $24 \%$ of hazardous waste was reported, later with the implementation of the project the registration index increased, in a percentage status of $64 \%$ obtaining a profit of $40 \%$; however, this is only part of the rendering of the application that is suggested to be followed up in a timely manner. 
With this result it is deduced that in the future each hazardous waste will be reported in time and form by the areas immersed in the process, this will bring about the improvement in the process of use and disposal of the materials, as well as the control of the levels production, and the benefit to the environment (Guerra, 2007). Regarding the monitoring of production levels by adjusting the order controls (input of raw material), the surplus material will be greatly reduced avoiding the generation of waste (Gutiérrez, 2010), which cause monetary losses and negative impacts. to the environment that is exposed by the presence of expired material.

Another benefit that is noted within the results of the OPEX application is that oriented to the environment, which brings with it the monitoring of the correct management of hazardous waste, the punctual record of expiration dates of substances and materials, the establishment of controls of production for the review, analysis and improvement of real usage, the analysis of hazardous waste generation lines and the creation of an action procedure for environmental aspects (Mejía, 2011).

The results obtained with Phase 3, which is identified by the implementation of the previously selected tools, brought with it the reduction of the main expired product (powder paint), which represented $29.5 \%$ of the registered hazardous material (Graph 1.3 Register of kg of powder paint generated).

\section{Kg. Of powder paint generated}

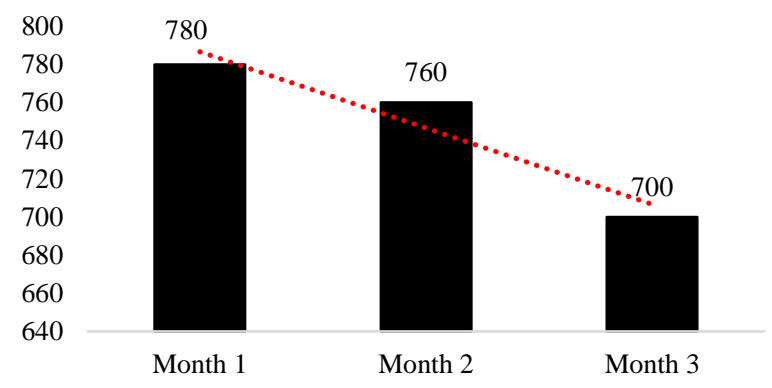

Graph 1.3 Register of kg of powder paint generated Source of consultation: Own Elaboration

As previously described, the monthly average of generated material was established at $902 \mathrm{~kg}$ per month (January-August 2020), with the implementation of OPEX in its initial phase (month 1), a record of $780 \mathrm{~kg}$ is observed, obtaining a benefit of $13.5 \%$, with respect to month 2 it reaches $15.74 \%$ and to end in month 3 the percentage benefit amounts to $22.4 \%$.
In such a way that the average benefit is 17.21\%; (Graph 1.3 Register of kg of powder paint generated). Now, in monetary terms, the monthly savings achieved is $\$ 46,724.62$.

\section{Thanks}

To the Higher Technological Institute of Huauchinango and the Industrial Engineering Division for the facilities granted for the preparation of the presented chapter.

\section{Conclusions}

The development of the Operational Excellence project (OPEX), satisfactorily responded to the objective, in the same way it served to identify areas of opportunity which, in turn, will allow the organization to become a leading ecological company worldwide, working to create a society based on recycling with a low carbon emission, through the application of a wide range of advanced technologies supported by the continuous actions of its employees and their high environmental commitment, which in relation to the powder paint residue already It was achieved in the short and medium, the only thing missing is the long term, which will be achieved when the strategy is applied to all the products handled by the warehouse.

In the same way, the contribution that was made is considered of utmost importance in the procedures of action of the main problems, which guides us to the common objective of a company, continuous improvement.

Returning to the relationship of the main objective that manifests the implementation of an effective strategy to reduce the negative impact of hazardous waste, it is stated that the generation of the main waste (powder paint) was reduced by an average of $17.21 \%$. It is important to mention that a complete situational analysis was carried out, which allowed carrying out the project, in the same way, strategies were formulated for the delivery of results and it was possible to evaluate the impact of the project on waste management through economic indicators (loss initial $=\$ 102,932.95$., final loss $=\$$ 46,724.62). 


\section{References}

American Assembly. (1982). The Binational American Assembly on the Border of the United States and México. El Paso, Texas. editorial. American Assembly, Columbia University. p.27.

Cuatrecasas, L. (2011). Organization of production and operations management: current efficient and competitive management systems. (1st. Ed.). Spain. Ediciones Díaz de Santos, S.A.

Dávila, A. Ponce, I.S., and Yandum, O. (2019). Comprehensive waste management. F. Natura, F (Natura).

Guerra, I. (2007). Evaluation and continuous improvement: concepts and tools for measuring and improving performance. 1st. Ed. United States. Authorhouse TM. ISBN 9781434339065.

Gutiérrez, H. (2010). Total Quality and Productivity. Mexico. Third edition. McGraw Hill / Interamericana Editores, S.A. de C.V. ISBN 978-607-15-0315-2.

Mejía, L.G. (2011). Biosafety Manual. Third edition. Centers for Disease Control and Prevention (CDC). Atlanta, GA, USA.

Mercader, F. (2002). Laboratory Waste Management. Querétaro, Mexico: National Metrology Center. Retrieved December 23, 2021.

Morejón, J. A. (2003). Regulation for the prevention and control of pollution by special waste. Quito: Special edition of executive function.

Navarro, E. (2003). Management and reengineering of processes. Available at http://sgpwe.izt.uam.mx/files/users/uami/jrmc/ Control_y_Gestion_Estrategicos_II/articulos_re latados/Gestion_y_reingenieria_de_procesos.pd f. Retrieved on December 23, 2021.

SEMARNAP. (1996). Program for the minimization and comprehensive management of hazardous industrial waste in Mexico 19962000. National Institute of Ecology, Mexico, 1996. p.165. 